\title{
A bibliometrical review on pre- and post- tsunami assumptions and facts about mangroves and other coastal vegetation as protective buffers
}

\author{
Farid Dahdouh-Guebas $^{1,2}$ \& Jayatissa Loku Pulukkuttige ${ }^{3}$
}

1 Laboratoire de Complexité et Dynamique des Système Tropicaux, Département de Biologie des Organismes, Faculté des Sciences, Université Libre de Bruxelles - ULB, CP 169, Avenue Franklin D. Roosevelt 50, B-1050 Bruxelles, Belgium Tel. +32 (0)2 6502137; Fax. + 32 (0)2 6252125; E-mail :fdahdouh@ulb.ac.be

2 Biocomplexity Research Focus c/o Laboratory of General Botany and Nature Management, Mangrove Management Group, Vrije Universiteit Brussel - VUB, Pleinlaan 2, B-1050 Brussel, Belgium. Tel. +32 (0)2 6293422; Tel. \& Fax. + 32 (0)2 6293413; Email :fdahdouh@vub.ac.be

3 Department of Botany, University of Ruhuna, Matara, Sri Lanka; Tel. +94 (041) 2227024; Fax.+94 (041) 22683; E-mail : 1pj@bot.ruh.ac.lk

\begin{abstract}
Using the Web of Science ${ }^{\circledR}$ database (Institute of Science Information - ISI, Philadelphia, PA, USA) we analysed pre- (1972-2004) and post-tsunami (2005) clues about the protective buffer offered by mangroves and other coastal vegetation in peer-reviewed ISI-rated scientific literature. Apart from providing a literature review on the above topic, this study reveals that papers dealing with or suggesting the protective function of mangroves have been well represented in scientific literature since the 1970s. However, high-profile journals and their associated media engine tremendously failed to pick up the importance of the scientific findings related to mangrove ecosystems. Apparently, the tsunami strike of 26 December 2004 raised the status of mangrove research overnight, and to a level that was of immediate interest to researchers in a broad range of other disciplines, and thus fit for high-profile journals. However, the database showed a highly significant inverse relationship between the impact factor of the journals in which posttsunami mangrove papers were published and the pre-tsunami mangrove expertise of the authors. While suggesting that the above trend is worrying, we present a research framework that should receive much more attention in research in the future by many journals of low and high impact factor. In the light of mangroves and protection against a wide range of water-related impacts - not only tsunamis but also cyclones, sea-level rise, daily tidal action and heavy El-Niño rains - it should be investigated which type of mangrove formation or coast-geomorphological settings has which effect. Root type, vegetation structure and species composition are categories with a lot of variation within, and may be considered in parallel with for instance a lagoon
\end{abstract}


setting with a fringing forest. Detangling the effect of such complexity under various water-related impacts will allow fully exploring and understanding the power of mangroves and other coastal vegetation as protective buffers. These priorities in fundamental research should be considered in parallel with research and policy measures on the conservation and restoration of mangroves, taking into account links with the socio-economic reality of local communities.

Keywords : mangrove, bibliometry, Web of Science ${ }^{\circledR}$, Mangrove Action Project, Impact Factor, tsunami, defence, barrier, protection, cyclone, hurricane, storm, ecosystem function, ecosystem service, future research directions.

\section{Introduction}

Tropical coasts face a dual problem : on one hand the population density is very high, and on the other hand a series of negative anthropogenic and natural impact cumulate in the coastal zone, such as water pollution, harbour and tourism-related development, consequences of cyclones or heavy rains, and tsunamis. Although a tsunami is limited in time and space, there are a number of local coast-geomorphological and climatological conditions and/or changes, or human factors that strengthen the impact of a tsunami. In the tropics, the natural systems that are often affected first by these phenomena are coral reefs, mangroves, seagrass beds, sand banks, dunes and other coastal vegetation. Mangrove forests generally occur in intertidal areas along tropical and subtropical coasts and stabilise the coastlines. They do not only function as 'living dykes', but also fulfil a protective role for coastlines that in turn form a physical buffer. The ecological importance of these forests is reflected by their function as breeding, spawning, hatching and nursing grounds for young development stages of fish and shellfish. The mangrove ecosystem also serves as a production unit of wood and are therefore of local and global socio-economic importance (Baran, 1999; Barbier \& Cox, 2002; Barbier, 2003). Apart from the increasing anthropogenic pressure on these ecosystems (e.g. by over-exploitation of mangrove wood, conversion for aquaculture, agriculture and oil spills) (Farnsworth and Ellison, 1997; Duke et al., 1997), also chronic impacts can leave traces that can be reinforced by global climate change. This global climate change, together with an increase in average temperatures and a rising sea level (incl. changes in sedimentation, soil texture, and origin of sediment, etc.), can result in an increase in the intensity of heavy storms (IPCC, 2001).

\section{The tsunami event and international articles}

On 26 December 2004 the world was shaken by one of the largest natural disasters in recent history; a seabed earthquake in the Indian Ocean caused an enormous ocean surge that hit the coasts of Sri Lanka, India, Thailand and Indonesia among others. With a measure of 9.0 on the Richter scale and a length of approximately $900 \mathrm{~km}$ along the megathrust rupture of the subduction zone between the India- and Burma plates, the earthquake was the strongest of the past 40 years (Bhattacharjee, 2005) and caused millions of homeless and hundred thousands of deadly casualties amongst the coastal people. The shift of the plates resulted in a 'killer-tsunami' that damaged 
many coastal settlements, but also the adjacent coastal ecosystems have severely suffered from the violence of nature.

Although the press - both the general and the scientific press writers such as Science, CNNworld, Newsweek, Courrier International, BioNieuws, etc. - has well highlighted the role of mangroves with respect to this tsunami, we have to acknowledge that hard scientific evidence is missing for both historic and recent ocean surges. The event of 26 December 2004 has received global attention and in various press releases the 'protective role' of mangrove ecosystems and the damage inflicted by the tsunami was highlighted. However, most reports were of very local nature and/or anecdotic (Danielsen et al., 2005; Liu et al., 2005), while others over-interpreted or minimalised the role of mangroves (Overdorf \& Unmacht, 2005). Both types of reports were criticised because of caveats or because they failed view the facts, results or assumptions against welldocumented and published papers (Dahdouh-Guebas et al., 2005c; Kathiresan \& Rajendran, 2005; Dahdouh-Guebas \& Koedam, 2006).

In the Web of Science ${ }^{\circledR}$ database, the only two analytical peer-reviewed publications based on medium to large scale investigations were conducted by Dahdouh-Guebas et al. (2005c), who focused on 24 mangrove lagoons in a coastal stretch of hundreds of kilometres along the Sri Lankan coast, and by Kathiresan \& Rajendran (2005), who investigated 18 fishermen hamlets in a coastal stretch of about $25 \mathrm{~km}$ in India. Kathiresan \& Rajendran (2005) investigated human death and loss of wealth in coastal villages in function of distance and elevation with respect to the sea, and in function of the type and area of coastal vegetation shielding the villages. Although the scientific basis of these results has been criticised by Kerr et al. (2006), who in turn has been criticised by Vermaat \& Thampanya (2006), the anecdotical value of the paper by Kathiresan \& Rajendran (2006) remains valid. Dahdouh-Guebas et al. (2005c) focused on tsunami damage inflicted on mangroves in function of pre-tsunami status of the forests and in function of cryptic ecological degradation ( $c f$. Dahdouh-Guebas et al., 2005b). However, despite all above papers, from a critical scientific point of view the question of mangroves have functioned as a buffer (or if they still function as such today) remains unanswered. Even more essential than this question is the thought that mangroves can function as a physical buffer, while protecting other coastal areas that in turn function also as a buffer (Nico Koedam, pers. comm.). Apparently, this has also never been investigated.

In addition, the approach and the findings that could result from an investigation that addresses the above questions in a planned scientific fashion, would not only be applicable within the framework of mangrove forests and tsunami protection, but particularly within the framework of mangroves and protection against a wide range of water-related impacts, among which cyclones, sea-level rise, daily tidal action, and heavy El-Niño rains ( $c f$. Badola \& Hussain, 2005). Although each of these impacts is characterised by typical waves or currents, and a characteristic sediment transport/erosion pattern, it remains almost certain that the mangrove as an ecosystem can form a positive physical buffer and that it can mitigate the impact of the above phenomena (Badola \& Hussain, 2005; Dahdouh-Guebas et al., 2005c). 


\section{Objectives}

This paper is a first step into an in-depth investigation of the tsunami-event, and has as first objective to review the assumptions and the facts about mangroves and other coastal vegetation as protective buffers from scientific literature. Rather than the simple compilation and presentation of a references list of peer-reviewed papers and information therein, this paper is brought as a bibliometrical analysis of that review. The aim of this bibliometrical analysis is to get insight on what science underlies the hypothesis of vegetation (with a large emphasis on mangroves) as a coastal defence, and on which was the publication venue. The latter is important as a measure of amount of wide publicity given to the results (i.e. not only within academic circles but also to the broad public), as this significantly varies with journal and with impact factor (see below). The second objective is to outline a number of problems related to international and multidisciplinary rehabilitation of tsunami-struck areas. And the final objective is to provide a research framework, or at least a number of ideas to learn from what happened, and to view the tsunami disaster area as a natural experiment and natural laboratory. The paper therefore aims at researchers of coastal vegetation, scientific journal editors interested in bibliometry, and national and international institutes and institutions concerned about coastal protection.

We want to highlight that all discussions about natural barriers against water-related phenomena such as the tsunami should be viewed in the light of what can be done, and not in the light of what cannot be done or what is useless. For example, tsunami impacts of apocalyptical magnitudes such as the ones described in Hills \& Mader (1997) or Bryant \& Nott (2001) overrule the objective of the present paper. In situ post-tsunami research on how natural barriers withstood the tsunami in areas where the tsunami reached apocalyptical dimensions (e.g. Banda Aceh) will inevitably lead to a rejection of the hypothesis that healthy coastal environments reduced tsunami damage (e.g. coral reefs in Baird et al., 2005). Such a conclusion is evident and pre-empted when focusing solely on a region where the tsunami was apocalyptical in nature, but it would be a grave error to generalize this. In addition, a lack of local and/or scientific knowledge and descriptions of the pre-tsunami status of potential barriers in study sites badly affected by the tsunami, will make any findings on the inability of natural coastal barriers to mitigate a tsunami impact questionable (maybe the barriers were unable to fulfil their function because of chronic human impact, but could have helped if left in healthy status). Likewise, terrestrial environments without such barriers and that were weakly affected, will make results on the ability of terrestrial environments to mitigate a tsunami impact equally questionable if pre-tsunami status is undocumented (maybe barriers mitigated the tsunami impact but were subsequently washed away).

\section{Material \& Methods}

\section{International databases}

One of the pillars of this bibliometric research is the Web of Science ${ }^{\circledR}$ (Institute of Science Information - ISI, Philadelphia, PA, USA). Web of Science ${ }^{\circledR}$ consists of five databases : Science Citation Index Expanded ${ }^{\mathrm{TM}}$, Social Sciences Citation Index ${ }^{\circledR}$, Arts \& Humanities Citation Index ${ }^{\circledR}$, Index Chemicus ${ }^{\circledR}$, and Current Chemical Reactions ${ }^{\circledR}$. The first three of these databases, on which we focused, fully cover peer-reviewed publications from more than 8,750 journals in all sciences (Agriculture, biology and environmental sciences; Physical, chemical and earth sciences; Engineering, computing and technology; Life sciences; Clinical medicine; Arts and humanities; 
Social and behavioural sciences), and it indexes individually selected, relevant items from over 10,000 of the world's leading scientific and technical journals. Web of Science ${ }^{\circledR}$ covers a period of 33 years (1972-2005, with occasional references published before 1972), and is updated weekly. Its limitations are that it only covers journals with an Impact Factor (which is also calculated by ISI), and not the numerous peer-reviewed journals without an Impact Factor. Without going into the details of the use and abuse of these databases or the Impact Factors (see Amin \& Mabe, 2001), its use is in itself not expected to be biased for the following reasons. First, a majority of researchers who build up a scientific publication record through peer-reviewed papers do not deliberately target those journals without an Impact Factor. In reality, researchers publish in both rated and non-rated journals. Second, the ISI databases are unfortunately the only existing international databases to carry out decadal retrospective bibliometric research on specific research areas, co-authorship patterns and so forth (Dahdouh-Guebas et al., 2003). There are no other international multidisciplinary databases that are organised, structured and updated on such a regular basis and that go back so far in time.

We also highlight that we are aware of numerous publications in the category of 'grey literature' or in the category of 'non-ISI-rated scientific literature'. We are also aware of a number of scholarly or popular books on mangrove forests (Tomlinson, 1986; Field, 1995; Field, 1996; Stafford-Deitsch, 1996; Spalding et al., 1997; Hogarth, 1999; De Lacerda, 2002; Saenger, 2002), as well as of reports published by global organisations such as Food and Agricultural Organisation (FAO), United Nations Environment Programme (UNEP) or United Natioans Educational, Scientific and Cultural Organsation (UNESCO). There are also electronic discussion lists or newsletters, among which the Mangrove Research Discussion List (ran by M. Van Keulen and hosted at Murdoch University, Perth, Australia; URL : http://lists.murdoch.edu.au/mailman/listinfo/mangrove) and the Mangrove Action Project News (ran by A. Quarto at Mangrove Action Project, Port Angeles, Washington, USA; URL : http://www.earthisland.org/map/). However, since no structured database similar to Web of Science ${ }^{\circledR}$ was available, and reaching completeness in this category is therefore virtually impossible, this category was dropped altogether. Pre-empting the results from this study in this methodological section, we emphasize that the above is not a shortcoming of the research. In fact, any addition of grey or non-ISI-rated literature is reinforcing the 'conservative' results presented in this review paper. This was explicitly the case for the archive of the Mangrove Action Project News.

\section{Search protocols}

The Web of Science ${ }^{\circledR}$ database was searched for the period between 1 January 1972 and 1 January 2006, which contained 31,109,001 publication records. We first filtered the database on the condition that the term 'mangrove' appeared in title, abstract or keyword fields (author keywords as well as extra database keywords). Papers on mangroves for which this condition was not true were therefore not retrieved, which may be considered a bias. However, the number of papers on a particular topic that does not list this topic in the title, in the keywords or in the abstract is negligible ( $c f$. Dahdouh-Guebas et al., 2003). In addition, the only way to overcome such a bias would be to actively read the full text of all 31.1 million papers, which is impracticable. The first conditional query of the full Web of Science ${ }^{\circledR}$ database generated a list of 3,878 publications. Within this list we extracted those papers that complied with the second condition that any of the following keywords appeared in title, abstract and keyword fields : 'tsunami', 
'defence', 'barrier', 'protection', 'storm', 'cyclone', 'hurricane', 'function' and 'service', all keywords that may highlight the ability of mangroves to function as a protective barrier against water-related phenomena such as cyclones, tsunamis, El-Niño events, and heavy rains. For each of these papers the abstract was read to ascertain that this emphasis was present to a minimal degree. For the keyword 'service' the entire paper was read to ascertain the same, since the reading of the abstract mostly generated inconclusive results. Whenever the above-mentioned emphasis was lacking in a paper it was omitted from further analysis. Note that papers with only a focus on these keywords (second condition) and without emphasis on mangroves (first condition) are not included in the quantitative analysis, e.g. the paper by Bryant et al. (1992) on the effect of palaeotsunamis on coastal areas of Australia was not included as it has no focus on mangroves. Likewise, many papers on the effect of sea-level rise on mangroves and not on the protection of the coast by mangroves were not selected (Woodroffe, 1990; Woodroffe et al., 1995; Woodroffe, 1999). However, some relevant studies amongst them were used in the discussion qualitatively.

In addition to the references resulting from the above protocol, all papers published between 1972 and $1991(n=787)$ were re-analysed, as the database does not list keywords or abstracts for this period. This means that the above automated protocol for this period could only be based on title information. By manual reading and interpreting the title context 28 additional papers were withheld, a majority of which were general ecological papers.

For the sake of completeness with respect to other coastal settings and vegetations that may have been reported as a protective barrier against tsunamis, we searched the original Web of Science ${ }^{\circledR}$ database ( 1 January 1972 and 1 January 2006) for the combination of the term 'tsunami' and each of the following terms : 'continental shelf', 'coral', 'dune', 'sand', 'sediment', 'soil' and 'vegetation'. This generated 264 extra papers, to which we applied the second condition as described above.

Finally, we highlight one more limitation to the use of the Web of Science ${ }^{\circledR}$ database. First, there may be a delay of several months before publication of a paper in a journal, and its appearance in the Web of Science ${ }^{\circledR}$ database. Some papers published in 2005 (most likely those published at the end of 2005) will have appeared after 1 January 2006. We have deliberately not investigated articles published at later stages (2006-present) in order to be able to discuss the immediacy of publication on a topic such as the tsunami disaster.

\section{Results}

Below we refer to papers on mangroves that were published before the tsunami hit (1972 to 2004), hereafter called 'pre-tsunami mangrove papers', and papers published after the disaster (2005), hereafter called 'post-tsunami mangrove papers'. Both types specifically refer to papers dealing with how well mangroves could or did withstand the impact of ocean surges (tsunami, cyclone). We also refer to general pre-tsunami mangrove papers of authors as a measure for their expertise on mangroves prior to the tsunami disaster. Note that the term 'pre-tsunami' refers to the time of publishing of general mangrove papers and not to papers on the tsunami-related topics.

According to the Web of Science ${ }^{\circledR}$ database 54 papers were published between 1972 and 2005 that highlighted the ability of mangroves to function as a buffer between land and sea (Table 1). In addition, there are six papers that link protection by coastal settings (such as shallow bays, sand 
banks, form of the continental shelf) or by coastal vegetation other than mangroves (e.g. sand dune vegetation) to tsunami impact sensu lato (Young \& Bryant, 1992; Delaney \& Devoy, 1995; Bryant \& Price, 1997; Bryant et al., 1997; Hindson et al., 1998; Tuttle et al., 2004).

There were five post-tsunami mangrove articles with in total 38 authors (Table 2). However, 29 of them (76\%) had no pre-tsunami mangrove publication record, 4 of them had three papers or less, and only 5 of them had a considerable pre-tsunami mangrove publication record (8 papers or more). A similar degree of opportunism was true for some of the journals in which the posttsunami mangrove papers were published (Table 3): while expecting a positive correlation, the relationship between the Impact Factor of these journals and the pre-tsunami mangrove expertise of the authors was negative (Figure 1). When omitting expected patterns from the relationship, i.e. authors with a lot of expertise who publish in journals with high Impact Factors, and authors with little expertise who publish in journals with low Impact Factors - this corresponds to a single study - the worrying underlying trend became even more clear : the higher the profile of the journal, the lower the pre-tsunami mangrove expertise of the authors who published a post-tsunami paper in it (Figure 1). The journal with the highest Impact Factor in this list (Science) published even two post-tsunami mangrove contributions, as well as a set of disaster-related viewpoint papers by experts (e.g. Adger et al., 2005; Allenby \& Fink, 2005; Linnerooth-Bayer et al., 2005; Mills, 2005), but just a single "mangrove" publication in the 30 years preceding the tsunami (Smith et $a l ., 2001)$. The latter paper focused on the remains of a dinosaur in mangrove deposits rather than on the mangrove itself, and was therefore excluded from further analysis. We do highlight that a recent paper on the macro-ecology of mangroves (Ellison, 2002) reported 4 papers published in Science, Nature, or Proceedings of the National Academy of Sciences of the USA in the period 1945-1972, but we were not able to obtain particulars about the reference to these papers.

Bibliometric retrospection over the past 33 years reveals that papers relating the mangrove ecosystem to shoreline protection have always existed and have significantly increased in number throughout the time period considered (Figure 2) ${ }^{1}$. However, the individual and average annual Impact Factor of the journals in which such papers get published have increased unmistakably since the tsunami disaster. Prior to 2005, however, one can only track 3 papers in Nature on mangroves. One of these is on the original topic of the distribution of ancient mangrove forests (Woodroffe et al., 1985). The remaining two papers were on the adverse effect of aquaculture on fish supplies (Naylor et al., 2000), and on the beneficial effect of mangroves on fish assemblages (Mumby et al., 2004), topics that have been recurrently dealt by many authors (e.g. Folke \& Kautsky, 1989, 1992; Primavera, 1997; Baran \& Hambrey, 1998; Barbier \& Strand, 1998; Boyd \& Clay, 1998; Baran, 1999; Folke et al., 1998; Dewalt et al., 1996). There is no other record of papers on mangroves, let alone on its ability to function as a natural dyke, in high-profile journals ${ }^{2}$.

As indicated in the methodology, any addition from grey literature to the above results reinforces them. The archive of the Mangrove Action Project News was in line with the trend observed for the Web of Science ${ }^{\circledR}$ database, i.e. highlights of the protective functions is recurrent over time, and boomed after the tsunami disaster.

\footnotetext{
${ }^{1}$ Inclusion of the six papers on non-mangrove coastal vegetation or coast-morphological settings that could fulfil the same protective function does not significantly alter the results or their further statistical analyses.

${ }^{2}$ The term 'high-profile' is based on the journals that cover a wide variety of topics in ecology and have an impact factor superior to 10 .
} 


\section{Discussion}

In contrast to recent claims that there are few field-based and quantitative studies of the shielding function of mangroves against wind-induced or tsunami waves (Danielsen et al., 2006) this bibliometric study shows that there have been numerous such reports. However, the fact that highprofile journals failed to pick up this research may be a factor in the world-wide publicity that this important ecosystem function has received. It is a feature of high-profile journals to report almost exclusively about scientific break-through studies and to compete for its publication with all consequences associated (e.g. Hwang, 2006), while disregarding many other studies that are equally fundamental or innovative and that may hold enormous indirect benefits to natural habitats and to the people living in association with these habitats. Unfortunately, mangrove forests have only become an "appealing topic in frontier science" after the tsunami struck, not before. The sad conclusion is that whereas mangrove forests have long been one of the most threatened ecosystems world-wide (Farnsworth \& Ellison, 1997; Alongi, 2002; FAO, 2003; Duke et al., 2007), and whereas they have a wide array of ecosystem functions and services ranging from fish and other food sources to physical protection of the coastal zone, a major tsunami with hundred thousands of deaths and millions of displaced victims in 12 countries were necessary in order to raise mangroveassociated research to a publication level that is of immediate interest to researchers in a broad range of other disciplines or that is not too narrowly focused on a particular geographic area.

Long before the tsunami disaster, Sri Lankan researchers reported that scientific research outputs in scientific journals with a low or with no Impact Factor were considered less relevant by governmental agencies than research published in high profile journals. This is in line with the world-wide publicity that high profile journal publications receive, which is in part a consequence of the press releases by the journals themselves. Also media agencies focus primarily on press releases by high profile journals rather than on scientific output by a wide range of journals. This vicious circle of mutual reinforcement between media and high-profile journals is of global nature and benefits only the papers that indeed get published in these journals. The lack of high-profile publications devoted to mangrove ecosystems has likely contributed to the lack of realisation of the benefits of mangroves world-wide. As a parallel we highlight the important globally recognized status of the Amazon forest, and the appearance of no less than 89 publications associated to this ecosystem in Science or Nature between 1998 and 2005 (see Web of Science ${ }^{\circledR}$ ). This has not entirely saved the Amazon forest from being deforested, but we maintain that it has helped or at least it is has raised a world-wide public concern. Instead of being similarly valued and protected, mangrove forests have been historically depicted as a breeding site for malaria, as a horrific area with dangerous wild animals (crocodiles, snakes,...), and as a purposeless forest (e.g. Von Rosenberg, 1867; Murphy, 1899). In the past century, numerous forms of mangrove destruction occurred, of which conversion to shrimp farms or tourist resorts, and over-exploitation are probably the most important ones (Farnsworth \& Ellison, 1997; Alongi, 2002; Dahdouh-Guebas, 2006). Apart from the loss of physical protection, this has resulted into disastrous consequences for local and global fish supplies (Barbier, 2000; Naylor et al., 2000), the worst effect of which is probably yet to come.

The best suggestion to the problem described above is that high-profile interdisciplinary journals should adopt no focus on certain topics within the disciplines they cover, and should look past scientific break-through and business-driven media attention when evaluating research papers. Future research should focus on the complexity of mangrove formations and their surroundings 
and all publication outlets should participate in reporting the results that will be highly relevant for nature, environment, science, economy, and subsistence populations.

\section{Framework for future research on the protection function of mangroves}

The precautionary principle dictates that we should carefully manage natural ecosystems because of their assumed functions, but the necessity for in-depth research is now announced. We generally assume that mangroves can mitigate the damage in landward settlements by absorbing the destructive impact of incoming waves, and many references were found that are in favour of this theory. However, this so-called evidence has never been proven or unravelled, which forms a shortcoming in fundamental scientific research on vegetation dynamics and sediment dynamics in mangroves. Particularly the typology (vegetational and geomorphological settings), species composition, and the dynamics (static or dynamic) of mangroves can vary considerably between mangrove forests and so can the degree to which they can protect a coastline. We propose that these are investigated in-depth in future research on the level of the organism, the vegetation assemblage and the ecosystem (Fig. 4). The research framework below is not associated to frameworks needed in general mangrove conservation or rehabilitation of tsunami-affected areas (cf. Adger et al., 2005; Barbier, 2006).

Vegetational typology and species composition cover a wide range of differences that are rarely considered. Different species imply different complexes of above-ground pneumatophores (i.e. aerial roots) : prop or stilt roots, pencil roots, peg roots, knee roots, plank roots and buttress roots (Fig. 4). Some species or some specimens within the species have well-developed roots, others may have no clear above-ground roots depending on environmental conditions (e.g. Heritiera spp.). It is assumed that this variety of roots lead to different degrees of protection against chronic or acute water-related events and disasters. The same is valid for the general physiognomy of a tree (particularly the stem and to a lesser degree the canopy), which is environment-dependent. Apart from the above aspects of the individual organism, similar physiognomic aspects can be described on a vegetation assemblage level, such as species composition, density, basal area, etc. (Fig. 4). These elements, which constitute the vegetation structure, can be structured as zones, partial zones or mosaic vegetation patches and the functionality of such vegetational types should be investigated in detail. Different mixes of species are indeed assumed to be a factor in degree of coastal protection, and so are the historic changes or vegetation structure dynamics that occur on the level of floristics and vegetation assemblages (cf. Dahdouh-Guebas \& Koedam, 2002). The causes of such change may have a natural component, or it may be anthropogenic, either directly or indirectly. On one hand, areas deteriorated by human activities or previous natural hazards may be even less functional in coastal protection. One example is provided by the effect termed 'cryptic ecological degradation' (Dahdouh-Guebas et al., 2005b), which was found to be a factor in protection against the tsunami (Dahdouh-Guebas i.e., 2005c). On the other hand, the above anthropogenic or natural impacts or stochastic events may increase the complexity of a forest and therefore the protection function (cf. Duke, 2001). Which of these contrasting views is correct in the light of physical protection is also subject to in-depth research.

The third level on which the research framework should focus is on the ecosystem level, which has been subdivided in a window on mangrove community and one on geomorphology. This level is in part overlapping and in part cross-cutting the above individual and assemblage 
levels. Mangrove community types, as defined by Lugo \& Snedaker (1974), include the following forest types : overwash, fringe, riverine, basin, hammock and scrub forest. Geomorphological settings include the river-dominated, the tide-dominated, the wave-dominated barrier lagoon, the composite river and wave dominated and the drowned bedrock valley setting defined by Thom (1984). It also includes the above-water elevation of the landscape and the underwater topography of the continental shelf.

From the above research framework levels it becomes clear that there is no typical level of protection by mangroves, but a wide range of different settings in a multi-dimensional space that need in-depth investigation instead.

Finding in situ examples of tsunami-struck areas or villages with comparable settings (i.e. equidistant from the sea, similar continental shelf, similar elevation, similar infrastructure and settlements) but with the difference that one is protected by a well-developed mangrove and one is open to the sea, is virtually impossible and counter-advised in view of scientific correctness ( $c f$. Dahdouh-Guebas \& Koedam, 2006). Rather than finding such test-examples, country-wide or regional assessments should be carried out, and future de novo research should focus on modelling the different types of settings in tanks. So far only one publication exists that directly investigates the effect by mangroves on wind-induced wave action (Massel et al., 1999), and it is limited to combined effects of drag caused by mangrove roots and trunks and bottom friction. The latter paper, which is in fact at the level of the tree ( $c f$. research framework above), is exemplary for the type of research that is needed, but then with a complexity different magnitudes larger. As indicated in the introduction, also the characteristic waves or currents, and the characteristic sediment transport/erosion pattern of water-related impacts (cyclones, sea-level rise, daily tidal action, and heavy El-Niño rains) are criteria that must be distinguished in this type of study ( $c f$. Wolanski, 1992, 1995; Mazda et al., 1995; Furukawa \& Wolanski, 1996; Furukawa et al., 1997; Mazda et al., 1997a, 1997b; Ridd et al., 1998; Mazda et al., 1999, 2002, 2005). Also the effect of floating debris (cf. Stieglitz \& Ridd, 2001; Krauss et al., 2005) on currents and waves may be a factor in such investigations.

\section{Acknowledgements}

This research is within the objectives of the International Geosphere-Biosphere Programme (IGBP), Past Global Changes (PAGES) Focus 5 : Past Ecosystem Processes and HumanEnvironment Interactions.

\section{References}

References have been subdivided as 'references in text' and 'References only in tables or figures, as part of the bibliometric analysis'. 


\section{References in text}

Adger, W.N., Hughes, T.P., Folke, C., Carpenter, S.R., Rockström, J., 2005. Social-ecological resilience to coastal disasters. Science 309, 1036-1039.

Allenby, B., Fink, J., 2005. Toward inherently secure and resilient societies. Science 309, 10341036.

Alongi, D.M., 2002. Present state and future of the world's mangrove forests. Environmental Conservation 29(3), 331-349.

Amin, M., Mabe, M., 2000. Impact Factors : use and abuse. Perspectives in Publishing 1, 1-6.

Badola, R., Hussain, S.A, 2005. Valuing ecosystem functions: an empirical study on the storm protection function of Bhitarkanika mangrove ecosystem, India. Environmental Conservation 32 (1), 85-92.

Baird, A.H., Campbell, S.J., Anggoro, A.W., Ardiwijaya, R.L., Fadli, N., Herdiana, Y., Kartawijaya, T., Mahyiddin, D., Mukminin, A., Pardede, S.T., Pratchett, M.S., Rudi, E., Siregar, A.M., 2005. Acehnese reefs in the wake of the Asian tsunami. Current Biology 15, 1926-1930.

Baran, E., Hambrey, J., 1998. Mangrove conservation and coastal management in southeast Asia : What impact on fishery resources? Marine Pollution Bulletin 37 (8-12), 431-440.

Baran, E., 1999. A review of quantified relationships between mangroves and coastal resources. Phuket Marine Biology Centre Research Bulletin 62, 57-64.

Barbier, E., Cox, M., 2002. Economic and demographic factors affecting mangrove loss in the coastal provinces of Thailand, 1979-1996. Ambio 31(4), 351-357.

Barbier, E.B., Strand, I., 1998. Valuing mangrove fishery linkages : a case study of Campeche, Mexico. Environmental and Resource Economics 12, 151-166.

Barbier, E.B., 2000. Valuing the environment as input : review of applications to mangrovefishery linkages. Ecological Economics 35, 47-61.

Barbier, E.B., 2003. Habitat-fishery linkages and mangrove loss in Thailand. Contemporary Economic Policy 21(1), 59-77.

Barbier, E.B., 2006. Natural barriers to natural disasters: replanting mangroves after the tsunami. Frontiers in Ecology and the Environment 4(3), 124-131.

Bhattacharjee, Y., 2005. Indian Ocean Tsunami: In Wake of Disaster, Scientists Seek Out Clues to Prevention. Science 307 (5706), 22-23.

Boyd, C.E., Clay, J.W., 1998. Shrimp aquaculture and the evironment. Scientific American June, 42-49.

Bryant, E.A., Price, D.M., 1997. Late Pleistocene marine chronology of the Gippsland Lakes region, Australia. Physical Geography 18(4), 318-334.

Bryant, E.A., Nott, J., 2001. Geological indicators of large tsunami in Australia. Natural Hazards 24(3), 231-249.

Bryant, E.A., Young, R.W., Price, D.M., 1997. Late Pleistocene marine deposition and TL chronology of the New South Wales, Australian coastline. Zeitschrift fur Geomorphologie 41(2), 205-227.

Bryant, E.A., Young, R.W., Price, D.M., Short, S.A., 1992. Evidence for Pleistocene and Holocene raised marine deposits, Sandon Point, New-South-Wales. Australian Journal of Earth Sciences 39(4), 481-493.

Dahdouh-Guebas, F., Koedam, N., 2002. A synthesis of existent and potential mangrove vegetation structure dynamics from Kenyan, Sri Lankan and Mauritanian case-studies. Meded. Zitt. K. Acad. overzeese Wet./Bull. Séanc. Acad. r. Sci. Outre-Mer 48(4), 487-511.

Dahdouh-Guebas, F., Koedam, N., 2006. Coastal vegetation and the Asian tsunami. Science 311, 37-38. 
Dahdouh-Guebas, F., 2006. Mangrove forests and tsunami protection. In : 2006 McGraw-Hill Yearbook of Science \& Technology, McGraw-Hill Professional, New York, USA: 187-191.

Dahdouh-Guebas, F., Ahimbisibwe, J., Van Moll, R., Koedam, N., 2003. Neo-colonial science by the most industrialised upon the least developed countries in peer-reviewed publishing. Scientometrics 56(3), 329-343.

Dahdouh-Guebas, F., Jayatissa, L.P., Di Nitto, D., Bosire, J.O., Lo Seen, D., Koedam, N., 2005c. How effective were mangroves as a defence against the recent tsunami? Current Biology 15(12), R443-447.

Dahdouh-Guebas, F., Hettiarachchi, S., Lo Seen, D., Batelaan, O., Sooriyarachchi, S., Jayatissa, L.P., Koedam, N., 2005b. Transitions in ancient inland freshwater resource management in Sri Lanka affect biota and human populations in and around coastal lagoons. Current Biology 15(6), 579-586.

Danielsen, F., Sørensen, M.K., Olwig, M.F., Selvam, V., Parish, F., Burgess, N.D., Hiraishi, T., Karunagaran, V.M., Rasmussen, M.S., Hansen, L.B., Quarto, A., Suryadiputra, N., 2005. The asian tsunami: A protective role for coastal vegetation. Science 310, 643.

Danielsen, F., Sørensen, M.K., Olwig, M.F., Selvam, V., Parish, F., Burgess, N.D., Hiraishi, T., Karunagaran, V.M., Rasmussen, M.S., Hansen, L.B., Quarto, A., Suryadiputra, N., 2006. Coastal vegetation and the Asian tsunami - Response. Science 311, 37-38.

De Lacerda, L.D., 2002. Mangrove Ecosystems: Function and Management. Springer-Verlag, Berlin, Germany. 314 pp.

Delaney, C., Devoy, R., 1995. Evidence from sites in Western Ireland of late Holocene changes in coastal environments. Marine Geology 124, 273-287.

Dewalt, B.R., Vergne, P., Hardin, M., 1996. Shrimp aquaculture development and the environment: People, mangroves and fisheries on the Gulf of Fonseca, Honduras. World Development 24(7), 1193-1208.

Duke, N.C., 2001. Gap creation and regenerative processes driving diversity and structure of mangrove ecosystems. Wetlands Ecology and Management 9, 257-269.

Duke, N.C., Pinzón, Z.S., Prada, M.C., 1997. Large-scale damage to mangrove forests following two large oil spills in Panama. Biotropica 29(1), 2-14.

Duke, N.C., J.-O. Meynecke, S. Dittmann, A.M. Ellison, K. Anger, U. Berger, S. Cannicci, K. Diele, K.C. Ewel, C.D. Field, N. Koedam, S.Y. Lee, C. Marchand, I. Nordhaus \& F. DahdouhGuebas, 2007. A world without mangroves? Science 317: 41-42.

Ellison, A.M., 2002. Macroecology of mangroves: large-scale patterns and processes in tropical coastal forests. Trees - Structure and Function 16(2/3), 181-194.

FAO, 2003. Status and trends in mangrove area extent worldwide. Wilkie, M.L. and Fortuna, S., eds., Forest Resources Assessment Working Paper No. 63. Forest Resources Division. FAO, Rome. Farnsworth, E.J., Ellison, A.M., 1997. The global conservation status of mangroves. Ambio 26(6), 328-334.

Field, C.D., 1995. Journey amongst mangroves. International Society of Mangrove Ecosystems, Okinawa, Japan. 140 pp.

Field, C.D., 1996. Restoration of Mangrove Ecosystems. International Society for Mangrove Ecosystems, Okinawa, Japan. 250 pp.

Folke, C., Kautsky, N., 1989. The role of ecosystems for a sustainable development of aquaculture. Ambio 18(4), 234-243.

Folke, C., Kautsky, N., 1992. Aquaculture with its environment : prospects for sustainability. Ocean and Aquaculture 17, 5-24.

Folke, C., Kautsky, N., Berg, H., Jansson, A., Troell, M., 1998. The ecological footprint concept for sustainable seafood production : a review. Ecological Applications 8(1), 63-71.

Furukawa, K., Wolanski, E., 1996. Sedimentation in Mangrove Forests. Mangroves and Salt Marshes 1(1), 3-10. 
Furukawa, K., Wolanski, E., Mueller, H., 1997. Currents and sediment transport in mangrove forests. Estuarine, Coastal and Shelf Science 44, 301-310.

Hills, J.G., Mader, C.L.,1997. Tsunami produced by the impacts of small asteroids. Annals of the New York Academy of Sciences 822, 381-394.

Hindson, R., Andrade, C., Parish, R., 1998. A microfaunal and sedimentary record of environmental change within the late Holocene sediments of Boca do Rio (Algarve, Portugal). Geologie en Mijnbouw - Netherlands Journal of Geosciences 77, 311-321.

Hogarth, P.J., 1999. The Biology of Mangroves. Oxford University Press Inc., New York, USA. $228 \mathrm{pp}$.

Hwang, W.S., 2006. Evidence of a pluripotent human embryonic stem cell line derived from a cloned blastocyst (Retraction of vol 303, pg 1669, 2004). Science 311(5759), 335-335.

IPCC, 2001. Climate Change 2001: The Scientific Basis. Contribution of Working Group I to the Third Assessment Report of the Intergovernmental Panel on Climate Change [Houghton, J.T.,Y. Ding, D.J. Griggs, M. Noguer, P.J. van der Linden, X. Dai, K. Maskell, and C.A. Johnson (eds.)]. Cambridge University Press, Cambridge, United Kingdom and New York, NY, USA, 881pp.

Kaplowitz, M.D., 2001a. Assessing mangrove products and services at the local level: The use of focus groups and individual interviews. Landscape and Urban Planning 56, 53-60.

Kaplowitz, M.D., 2001b. Uncovering economic benefits of chivita (Melongena melongena Linnaeus, 1758 and Melongena corona bispinosa Philippi, 1844). Journal of Shellfish Research 20(1), 317-321.

Kathiresan, K., Rajendran, N., 2005. Coastal mangrove forests mitigated tsunami. Estuarine, Coastal and Shelf Science 65, 601-606.

Kerr, A.M., Baird, A.H., Campbell, S.J., 2006. Comments on "Coastal mangrove forests mitigated tsunami' ' by K. Kathiresan and N. Rajendran [Estuar. Coast. Shelf Sci. 65 (2005) 601606]. Estuarine, Coastal and Shelf Science 67, 539-541.

Krauss, K.W., Doyle, T.W., Twilley, R.R., Smith III, T.J., Whelan, K.R.T., Sullivan, J.K., 2005. Woody debris in the mangrove forests of South Florida. Biotropica 37(1), 9-15.

Linnerooth-Bayer, J., Mechler, R., Pflug, G., 2005. Refocusing disaster aid. Science 309, 10441046.

Liu, P.L.-F., Lynett, P., Fernando, H., Jaffe, B.E., Fritz, H., Higman, B., Morton, R., Goff, J., Synolakis, C., 2005. Observations by the international tsunami survey team in Sri Lanka. Science 308, 1595.

Lugo, A.E., Snedaker, S.C., 1974. The ecology of mangroves. Annual Review of Ecology and Systematics 5,: 39-64.

Massel, S.R., Furukawa, K., Brinkman, R.M., 1999. Surface wave propagation in mangrove forests. Fluid Dynamics Research 24(4), 219-249.

Mazda, Y., Kobashi, D., Okada, S., 2005. Tidal-scale hydrodynamics within mangrove swamps. Wetlands Ecology and Management 13(6), 647-655.

Mazda, Y., Wolanski, E., King, B., Sase, A., Ohtsuka, D., Magi, M., 1997b. Drag force due to vegetation in mangrove swamps. Mangroves and Salt Marshes 1(3), 193-199.

Mazda, Y., Magi, M., Nanao, H., Kogo, M., Miyagi, T., Kanazawa, N., Kobashi, D., 2002. Coastal erosion due to long-term human impact on mangrove forests. Wetlands Ecology and Management 10, 1-9.

Mazda, Y., Magi, M., Kogo, M., Hong, P.N., 1997a. Mangroves as a coastal protection from waves in the Tong King Delta, Vietnam. Mangroves and Salt Marshes 1, 127-135.

Mazda, Y., Kanazawa, N., Wolanski, E., 1995. Tidal asymmetry in mangrove creeks. Hydrobiologia 295, 51-58.

Mazda, Y., Kanazawa, N., Kurokawa, T., 1999. Dependence of dispersion on vegetation density in a tidal creek mangrove swamp system. Mangroves and Salt Marshes 3(1), 59-66. 
Mumby, P.J., Edwards, A.J., Arlas-González, J.E., Lindeman, K.C., Blackwell, P.G., Gall, A., Gorczynska, M.I., Harborne, A.R., Pescod, C.L., Renken, H., Wabnitz, C.C.C., Llewellyn, G., 2004. Mangroves enhance the biomass of coral reef fish communities in the Caribbean. Nature 427, 533-536.

Murphy, J.M., 1899. Alligator shooting in Florida. In : F. Oppel and T. Meisel (Eds). Tales of Old Florida. Castle, 1987, Secaucus, New Jersey, USA: 353-364.

Naylor, R.L., Goldburg, R.J., Primavera, J.H., Kautsky, N., Beveridge, M.C.M., Clay, J., Folke, C., Lubchenco, J., Moony, H., Troell, M., 2000. Effect of aquaculture on world fish supplies. Nature 405(29), 1017-1024.

Primavera, J.H., 1997. Socio-economic impacts of shrimp culture. Aquaculture Research 28, 815827.

Ridd, P.V., Stieglitz, T., Larcombe, P., 1998. Density-driven secondary circulation in a tropical mangrove estuary. Estuarine, Coastal and Shelf Science 47(5), 621-632.

Saenger, P., 2002. Mangrove ecology, silviculture and conservation. Kluwer Academic Publishers, Dordrecht, The Netherlands. 360 pp.

Smith, J., Lamanna, B., Metthew, C., Lacovara, K.J., Dodson, P., Smith, J.R., Poole, J.C., Giegengack, R., Attia, Y., 2001. A giant sauropod dinosaur from an upper cretaceous mangrove deposit in Egypt. Science 292(5522), 1704-1706.

Spalding, M., F. Blasco \& C. Field, 1997. World Mangrove Atlas. The International Society for Mangrove Ecosystems, Okinawa, Japan. 178 pp.

Stafford-Deitsch, J., 1996. Mangrove : the Forgotten Habitat. Immel Publishing Limited, London, UK. 277 pp.

Stieglitz, T., Ridd, P.V., 2001. Trapping of mangrove propagules due to density-driven secondary circulation in the Normanby River estuary, NE Australia. Marine Ecology Progress Series 211, 131-142.

Thom, B.G., 1984. Coastal landforms and geomorphic processes. In : The mangrove ecosystem : research methods. Snedaker, S.C. \& J.G. Snedaker, eds. UNESCO, Paris, France, 3-17.

Tomlinson, P.B., 1986. The Botany of Mangroves. Cambridge University Press, Cambridge, UK. $419 \mathrm{pp}$.

Tuttle, M.P., Ruffman, A., Anderson, T., Jeter, H., 2004. Distinguishing tsunami from storm deposits in eastern North America: The 1929 grand banks tsunami versus the 1991 Halloween storm. Seismological Research Letters 75(1), 117-131.

Von Rosenberg, C.B.H., 1867. Reis naar de Zuidoostereilanden gedaan in 1865 op last der Regering van Nederlandsch-Indie. Martinus Nijhoff, 's Gravenhage, The Netherlands.

Wolanski, E., 1992. Hydrodynamics of mangrove swamps and their coastal waters. Hydrobiologia 247, 141-161.

Wolanski, E., 1995. Transport of sediment in mangrove swamps. Hydrobiologia 295: 31-42.

Woodroffe, C.D., 1990. The impact of sea-level rise on mangrove shorelines. Progress in Physical Geography 14(4), 483-520.

Woodroffe, C.D., 1995. Response of tide-dominated mangrove shorelines in northern Australia to anticipated sea-level rise. Earth Surface and Landforms 20, 65-85.

Woodroffe, C.D., 1999. Response of mangrove shorelines to sea-level change. Tropics 8(3), 159177.

Woodroffe, C.D., Thom, B.G., Chappell, J., 1985. Development of widespread mangrove swamps in mid-Holocene times in Northern Australia. Nature 317(6039), 711-713. 


\section{References only in tables or figures, as part of the bibliometric analysis}

Abuodha, P.A.W., Kairo, J.G., 2001. Human-induced stresses on mangrove swamps along the Kenyan coast. Hydrobiologia 458, 255-265.

Acker, S., 1972. Mangrove ecology. Oceans 5(4), 34-43.

Aleem, A.A., 1990. Impact of human activity on marine habitats along the Red Sea coast of Saudi-Arabia. Hydrobiologia 208, 7 -15.

Amadi, A.A., 1990. A comparative ecology of estuaries in Nigeria. Hydrobiologia 208, 27-38.

Anthony, E.J., 2004. Sediment dynamics and morphological stability of estuarine mangrove swamps in Sherbro Bay, West-Africa. Marine Geology 208, 207-224.

Arrow, K., Daily, G., Dasgupta, P., Levin, S., Mäler, K.L., Maskin, E., Starrett, D., Sterner, T., Tietenberg, T., 2000. Managing Ecosystem Resources. Environmental Science and Technology 34, 1404-1406.

Bacon, P.R., Alleng, G.P., 1992. The management of insular Caribbean mangroves in relation to site location and community type. Hydrobiologia 247, 235-241.

Bandyopadhyay, S., 1997. Natural environmental hazards and their management: A case study of Sagar Island, India. Singapore Journal of Tropical Geography 18(1), 20-45.

Barbier, E.D., 1993. Sustainable use of wetlands - Valuing tropical wetland benefits - Economic methodologies and applications. Geographical Journal 159(1), 22-32.

Barbosa, F.M.A., Cuambe, C.C., Bandeira, S.O., 2001. Status and distribution of mangroves in Mozambique. South African Journal of Botany 67(3), 393-398.

Blasco, F., Bellan, M.F., Chaudhury, M.U., 1992. Estimating the extent of floods in Bangladesh using SPOT data. Remote Sensing of Environment 39(3), 167-178.

Boyer, T., Polasky, S., 2004. Valuing urban wetlands: A review of non-market valuation studies. Wetlands 24(4), 744-755.

Branch, G.M., Grindley, J.R., 1979. Ecology of southern African estuaries. 11. MngazanaMangrove estruary in Transkei. South African Journal of Zoology 14(3), 149-170.

Bruder, J.S., Large, E.G., Stark, B.L., 1975. Test of aerial photography in an estuarine mangrove swamp in Veracruz, Mexico. American Antiquity 40(3), 330-337.

Buckley, R.C., 1982. Patterns in North Queensland mangrove vegetation. Australian Journal of Ecology 7(1), 103-106.

Chee, Y.E., 2004. An ecological perspective on the valuation of ecosystem services. Biological Conservation 120(4), 549-565.

Choong, E.T., Wirakusumah, R.S., Achmadi, S.S., 1990. Mangrove forest resources in Indonesia. Forest Ecology and Management 33(4), 45-57.

Clüsener-Godt, M., 2002. Asia Pacific co-operation for the sustainable use of renewable natural resources in biosphere reserves and similarly managed areas. Trees 16, 230-234.

De Lacerda, L.D., Hay, J.D., 1982. Evolution of a new community type during the degradation of a mangrove ecosystem. Biotropica 14(3), 238-239.

Ewel, K.C., 2001. Natural resource management: The need for interdisciplinary collaboration. Ecosystems 4(8), 716-722.

Ewel, K.C., Twilley, R.R., Ong, J.E., 1998. Different kinds of mangrove forests provide different goods and services. Global Ecology and Biogeography Letters 7, 83-94.

Farnsworth, E.J., 1998. Issues of spatial, taxonomic and temporal scale in delineating links between mangrove diversity and ecosystem function. Global Ecology and Biogeography Letters 7, 15-25.

Ferdon, E.N., 1981. Holocene mangrove formations on the Santa Elena pensinsula, Ecuador Pluvial indicators or ecological response to physiographic changes. American Antiquity 46(3), 619-626. 
Field, C., 1998. Rationales and practices of mangrove afforestation. Marine and Freshwater Research 49(4), 353-358.

Field, C.B., Osborn, J.G., Hoffman, L.L., Polsenberg, J.F., Ackerly, D.D., Berry, J.A., Björkman, O., Held, A., Matson, P.A., Mooney, H.A., 1998. Mangrove biodiversity and ecosystem function. Global Ecology and Biogeography Letters 7, 3-14.

Field, C.D., 1999. Mangrove rehabilitation : choice and necessity. Hydrobiologia 413, 47-52.

Gilbert, A.J., Janssen, R., 1998. Use of environmental functions to communicate the values of a mangrove ecosystem under different management regimes. Ecological Economics 25(3), 323-346.

Halide, H., Brinkman, R., Ridd, P., 2004. Designing bamboo wave attenuators for mangrove plantations. Indian Journal or Marine Sciences 33(3), 220-225.

Hester, M.W., Spalding, E.A., Franze, C.D., 2005. Biological resources of the Louisiana coast: Part 1. An overview of coastal plant communities of the Louisiana Gulf shoreline. Journal of Coastal Research 44, 134-145.

Ibrahim, S., Hashim, I., 1990. Classification of mangrove forest by using 1-40000-scale aerial photographs. Forest Ecology and Management 33(4), 583-592.

Iftekhar, M.S., Islam, M.R., 2004. Degeneration of Bangladesh's Sundarbans mangroves : a management issue. International Forestry Review 6(2), 123-135.

Kaly, U.L., Jones, G.P., 1998. Mangrove restoration: A potential tool for coastal management in tropical developing countries. Ambio 27(8), 656-661.

Klein, R.J.T., Nicholls, R.J., Ragoonaden, S., Capobianco, M., Aston, J., Buckley, E.N., 2001. Technological options for adaptation to climate change in coastal zones. Journal of Coastal Research 17(3), 531-543.

Lakshmanan, K.K., Rajeswari, M., Jayalakshmi, R., Diwakar, K.M., 1984. Mangrove forest of Krusadai Island, S.E. India, and its management. Environmental Conservation 11(2), 174-176.

Lee, S.Y., 1999. Tropical mangrove ecology : physical and biotic factors influencing ecosystem structure and function. Australian Journal of Ecology 24, 355-366.

Lescure, J.P., 1980. Architectural survey of the mangrove of Guadeloupe. Acta Oecologica Oecologia Generalis 1(3), 249-265.

Lindén, O., Jernelöv, A., 1980. The mangrove swamp - An ecosystem in danger. Ambio 9(2), 8188.

Lugo, A.E., 1980. Mangrove ecosytems - Successional or steady-state. Biotropica 12S, 65-72.

Martinez, J.O., Gonzalez, J.L., Pikley, O.H., Neil, W.J., 1995. Tropical barrier islands of Colombia Pacific coasts. Journal of Coastal Research 11(2), 432-453.

Martinez-Alier, J., 2001. Ecological conflicts and valuation : mangroves versus shrimps in the late 1990s. Environment and Planning C : Government and Policy 19, 713-728.

Mildenhall, D.C., Brown, L.J., 1987. An early Holocene occurrence of the mangrove Avicennia marina in Poverty Bay, North Island, New Zealand : its climatic and geological implications. New Zealand Journal of Botany 25, 281-294.

Mills, E., 2005. Insurance in a climate of change. Science 309, 1040-1044.

Mimura, N., Nunn, P.D., 1998. Trends of beach erosion and shoreline protection in rural Fiji. Journal of Coastal Research 14(1), 37-46.

Moberg, F., Rönnbäck, P., 2003. Ecosystem services of the tropical seascape : interactions, substitutions and restoration. Ocean and Coastal Management 46, 27-46.

Naidoo, G., Raiman, F., 1982. Some physical and chemical properties of mangrove soils at Sipingo and Mgeni, Natal. South African Journal of Botany 1(4), 85-90

Nicholls, R.J., Hoozemans, F.M.J., Marchand, M., 1999. Increasing flood risk and wetland losses due to global sea-level rise : regional and global analyses. Global Environmental Change 9, S69S87.

Oo, N.W., 2002. Present state and problems of mangrove management in Myanmar. TreesStructure and Function 16, 218-223. 
Pannier, F., 1979. Mangroves impacted by human-induced disturbances - Case-study of the Orinoco Delta mangrove ecosystem. Environmental Management 3(3), 205-216.

Pearce, F., 1996. Living sea walls keep floods at bay. New Scientist 150(2032), 7-7.

Pearce, F., 1999. An unnatural disaster - Clearing India's mangrove forests has left the coast defenceless. New Scientist 164(2211), 12-12.

Plaziat, J.C., Koeniguer, J.C., Baltzer, F.,1983. From present to ancient mangrove swamps. Bulletin de la Société Geologique de France 25(4), 499-504.

Pool, D.J., Snedaker, S.C., Lugo, A.E., 1977. Structure of mangrove forests in Florida, PuertoRico, Mexico and Costa-Rica. Biotropica 9(3), 195-212.

Primavera, J.H., 1995. Mangroves and brakishwater pond culture in the Philippines. Hydrobiologia 295, 303-309.

Ramachandran, S., Anitha, S., Balamurugan, V., Dharanirajan, K., Vendhan, K.E., Divien, M.I.P., Vel, A.S., Hussain, I.S., Udayaraj, A., 2005. Ecological impact of tsunami on nicobar islands (Camorta, Katchal Nancowry and Trinkat). Current Science 89(1), 195-200.

Ron, J., Padilla, J.E., 1999. Preservation or conversion? Valuation and evaluation of a mangrove forest in the Philippines. Environmental Resource Economics 14(3), 297-331.

Rönnbäck, P., Primavera, J.H., 2000. Illuminating the need for ecological knowledge in economic valuation of mangroves under different management regimes - a critique. Ecological Economics 35(2), 135-141.

Rönnbäck, P., 1999. The ecological basis for economic value of seafood production supported by mangrove ecosystems. Ecological Economics 29, 235-252.

Ruitenbeek, R.H., 1994. Modeling economy ecology linkages in mangroves - economic evidence for promoting conservation in Bintuni Bay, Indonesia. Ecological Economics 10(3), 233-247.

Rutzler, K., Feller, C., 1987. Mangrove swamp communities. Oceanus 30(4), 16-24.

Saenger, P., Siddiqi, N.A., 1993. Land from the sea - the mangrove afforestation program of Bangladesh. Ocean and Coastal Management 20(1), 23-39.

Sathirathai, S., Barbier, E.B., 2001. Valuing mangrove conservation in southern Thailand. Contemporary Economic Policy 19(2), 109-122.

Semeniuk, V., 1980. Mangrove zonation along an eroding coastline in King Sound, Northwestern Australia. Journal of Ecology 68(3), 789-812.

Sherrod, C. L., McMillan, C., 1985. The distributional history and ecology of mangrove vegetation along the Northern Gulf of Mexico coastal region. Contributions in Marine Science 28, 129-140.

Singh, V.P., Garge, A., Pathak, S.M., Mall, L.P., 1987. Pattern and process in mangrove forests of the Andaman Islands. Vegetatio 71, 185-188.

Singh, V.P., Garge, A., Pathak, S.M., Mall, L.P., 1986. Mangrove forests of Andaman Islands in relation to human interference. Environmental Conservation 13(2), 169-172.

Tri, N.H., Adger, W.N., Kelly, P.M., 1998. Natural resource management in mitigating climate impacts : the example of mangrove restoration in Vietnam. Global Environmental Change 8(1), 49-61.

Twilley, R.R., Rivera-Monroy, V.H., 2005. Developing performance measures of mangrove wetlands using simulation models of hydrology, nutrient biogeochemistry, and community dynamics. Journal Coastal Research 40, 79-93.

Vannucci, M., 1988. The UNDP UNESCO mangrove program in Asia and the Pacific. Ambio 17(3), 214-217.

Williams, N., 2005. Tsunami insight to mangrove value. Current Biology 15(3), R73-R73.

Wolanski, E., Jones, M., Bunt, J.S., 1980. Hydrodynamics of a tidal creek mangrove swamp system. Australian Journal of Marine and Freshwater Research 31(4), 431-450.

Wong, P.P., 2003. Where have all the beaches gone ? Coastal erosion in the tropics. Singapore Journal of Tropical Geography 24(1), 111-132. 
Woodroffe, C.D., 1982. Geomorphology and development of mangrove swamps, Grand Cayman Island, West-Indies. Bulletin of Marine Science 32(2), 381-398.

Woodroffe, C.D., 1983. Development of mangrove swamps behind beach ridges, Grand Cayman Island, West-Indies. Bulletin of Marine Science 33(4), 864-880.

Yap, H.T., 2000. The case for restoration of tropical coastal ecosystems. Ocean \& Coastal Management 43(8-9), 841-851.

Young, R.W., Bryant, E.A., 1992. Catastrophic wave erosion on the southeastern coast of Australia - Impact of the Lanai tsunamis CA-105-KA. Geology 20(3), 199-202.

Table 1. Publications in the Web of Science ${ }^{\circledR}$ database (ISI) that relate 'mangrove' with one or more keywords below sensu lato. Note that the interest lies in the power of mangroves to protect the coastal zone; e.g. papers on 'protection' are not about 'protection of the mangrove' but about 'protection by the mangrove' (coastal protection, shoreline protection), or papers on 'hurricane' are not on 'hurricane impact on the mangrove' but about the 'impact reduced by mangroves'. The 54 publications do not differentiate between news items, short communications, full research papers, etc. Although multiple keywords may be applicable to a specific paper, the references listed are listed only once (under the prime keyword).

\begin{tabular}{|c|c|c|}
\hline Keyword 'tsunami' & Keyword 'function' & Keyword 'protection' \\
\hline $\begin{array}{l}\text { Bryant et al. (1992) } \\
\text { Dahdouh-Guebas et al. (2005) } \\
\text { Danielsen } \text { et al. (2005) } \\
\text { Kathiresan \& Rajendran (2005) } \\
\text { Liu et al. (2005) } \\
\text { Martinez (1995) } \\
\text { Ramachandran } \text { et al. (2005) } \\
\text { Williams (2005) }\end{array}$ & $\begin{array}{l}\text { Farnsworth (1998) } \\
\text { Field et al. (1998) } \\
\text { Gilbert \& Janssen (1998) } \\
\text { Iftekhar \& Islam (2004) } \\
\text { Kaly \& Jones (1998) } \\
\text { Lee (1999) } \\
\text { Moberg \& Rönnbäck (2003) } \\
\text { Rönnbäck (1999) }\end{array}$ & \multirow{9}{*}{$\begin{array}{l}\text { Alongi ( 2002) } \\
\text { Bacon \& Alleng (1992) } \\
\text { Badola \& Hussain (2005) } \\
\text { Barbier (1993) } \\
\text { Barbosa et al. (2001) } \\
\text { Clüsener-Godt (2002) } \\
\text { Ewel et al. (1998) } \\
\text { Field (1998) } \\
\text { Field (1999) } \\
\text { Halide et al. (2004) } \\
\text { Hester et al. (2005) } \\
\text { Klein et al. (2001) } \\
\text { Mimura \& Nunn (1998) } \\
\text { Oo (2002) } \\
\text { Saenger \& Siddiqi (1993) } \\
\text { Sathirathai \& Barbier (2001) } \\
\text { Wong (2003) }\end{array}$} \\
\hline Keyword 'service' & $\begin{array}{l}\text { Ruitenbeek (1994) } \\
\text { Twilley et al. (2005) }\end{array}$ & \\
\hline \multirow{7}{*}{$\begin{array}{l}\text { Boyer \& Polasky (2004) } \\
\text { Chee (2004) } \\
\text { Abuodha \& Kairo (2001) } \\
\text { Ewel (2001) } \\
\text { Martinez-Alier (2001) } \\
\text { Kaplowitz (2001a) } \\
\text { Kaplowitz (2001b) } \\
\text { Rönnbäck \& Primavera (2000) } \\
\text { Yap (2000) } \\
\text { Arrow et al. (2000) } \\
\text { Ron \& Padilla (1999) } \\
\text { Primavera (1997) } \\
\text { Primavera (1995) }\end{array}$} & & \\
\hline & $\begin{array}{l}\text { Keyword 'defence' or } \\
\text { 'defense' }\end{array}$ & \\
\hline & $\begin{array}{l}\text { Pearce (1996) } \\
\text { Pearce (1999) } \\
\text { Nicholls et al. (1999) } \\
\text { Tri et al. (1998) } \\
\end{array}$ & \\
\hline & $\begin{array}{l}\text { Keyword 'cyclone' or } \\
\text { 'hurricane' or 'storm' }\end{array}$ & \\
\hline & $\begin{array}{l}\text { Bandyopadhyay (1997) } \\
\text { Blasco et al. (1992) }\end{array}$ & \\
\hline & Keyword 'barrier' & \\
\hline & Anthony (2004) & \\
\hline
\end{tabular}

Table 2. Pre-tsunami mangrove expertise expressed as number of papers on mangroves listed in the Web of Science ${ }^{\circledR}$ database (ISI) for all authors of post-tsunami mangrove publications (in alphabetical order). News items or introductory editorial matter were excluded from the search in 
order to focus on research output (research papers, review papers, essays, short communications). See text for description of database filtering and its limitations. First authors are printed in bold.

\begin{tabular}{|c|c|c|}
\hline $\begin{array}{l}\text { Author post-tsunami } \\
\text { mangrove paper on } \\
\text { the impact of the } \\
\text { tsunami } \\
(2005)\end{array}$ & $\begin{array}{c}\text { Number of } \\
\text { general pre-tsunami } \\
\text { mangrove papers } \\
(1972-2004)\end{array}$ & Journal of post-tsunami paper \\
\hline Anitha S. & 0 & Current Science \\
\hline Balamurugan V. & 0 & Current Science \\
\hline Bosire J.O. & 3 & Current Biology \\
\hline Burgess N.D. & 0 & Science \\
\hline Dahdouh-Guebas F. & 15 & Current Biology \\
\hline Danielsen F. & 2 & Science \\
\hline Dharanirajan K. & 0 & Current Science \\
\hline Di Nitto D. & 0 & Current Biology \\
\hline Divien M.I.P. & 0 & Current Science \\
\hline Fernando H. & 0 & Science \\
\hline Fritz H. & 0 & Science \\
\hline Goff J. & 0 & Science \\
\hline Hansen L.B. & 0 & Science \\
\hline Higman B. & 0 & Science \\
\hline Hiraishi T. & 0 & Science \\
\hline Hussain I.S. & 0 & Current Science \\
\hline Jaffe B.E. & 0 & Science \\
\hline Jayatissa L.P. & 2 & Current Biology \\
\hline Karunagaran V.M. & 0 & Science \\
\hline Kathiresan K. & 39 & $\begin{array}{l}\text { Estuarine, Coastal and Shelf } \\
\text { Science }\end{array}$ \\
\hline Koedam N. & 22 & Current Biology \\
\hline Liu P.L.-F. & 0 & Science \\
\hline Lo Seen D. & 0 & Current Biology \\
\hline Lynett P. & 0 & Science \\
\hline Morton R. & 0 & Science \\
\hline Olwig M.F. & 0 & Science \\
\hline Parish F. & 0 & Science \\
\hline Quarto A. & 0 & Science \\
\hline Rajendran N. & 10 & $\begin{array}{l}\text { Estuarine, Coastal and Shelf } \\
\text { Science }\end{array}$ \\
\hline Ramachandran S. & 1 & Current Science \\
\hline Rasmussen M.S. & 0 & Science \\
\hline Selvam V. & 8 & Science \\
\hline Sørensen M.K. & 0 & Science \\
\hline Suryadiputra N. & 0 & Science \\
\hline Synolakis C. & 0 & Science \\
\hline Udayaraj A. & 0 & Current Science \\
\hline Vel A.S. & 0 & Current Science \\
\hline Vendhan K.E. & 0 & Current Science \\
\hline
\end{tabular}


Table 3. Number of general pre-tsunami mangrove papers listed in the Web of Science ${ }^{\circledR}$ database (ISI) for journals of post-tsunami mangrove publications (in alphabetical order). See text for description of database filtering and its limitations.

\begin{tabular}{|l|c|c|}
\hline $\begin{array}{c}\text { Journal post-tsunami mangrove paper on } \\
\text { the impact of the tsunami } \\
(\mathbf{2 0 0 5 )}\end{array}$ & $\begin{array}{c}\text { Impact Factor } \\
\mathbf{( 2 0 0 4 )}\end{array}$ & $\begin{array}{c}\text { Number of } \\
\text { pre-tsunami } \\
\text { mangrove papers } \\
\text { (1972-2004) }\end{array}$ \\
\hline Current Biology & 11.901 & 0 \\
\hline Current Science & 0.688 & 37 \\
\hline Estuarine, Coastal and Shelf Science & 1.058 & 130 \\
\hline Science & 31.853 & $1^{*}$ \\
\hline
\end{tabular}

- This paper focused on the remains of a dinosaur in mangrove deposits and not on the mangrove sensu stricto.

\section{Figure captions}

Figure 1. Relationship between the pre-tsunami mangrove expertise of the authors of a post-tsunami mangrove paper (each represented by a dot), and the Impact Factor of the journal in which this post-tsunami paper was published. The grey dashed line indicates the expected trend, and the grey dashed circles the locations of outliers to the underlying trend. Studies that followed the expected trend and that were outliers to the underlying trend (the single grey dot, corresponding to Ramachandran et al., 2005) were omitted from the correlation and regression analysis of the underlying trend (solid black line).

Figure 2. Number of pre- and post-tsunami mangrove papers (as recorded in the Web of Science ${ }^{\circledR}$ database) dealing with how well mangroves could or did withstand the impact of ocean surges, published between 1972 and 2005. The data also contain the six papers on non-mangrove coastal vegetation and coast-morphological

settings that could have the same protective effect, which does not significantly influence the statistical analysis (see text). There is a significantly increasing trend in number of papers (Acker, 1972; Bruder et al., 1975; Pool et al., 1977; Branch \& Grindley, 1979; Pannier, 1979; Lescure et al., 1980; Lindén \& Jernelöv, 1980; Lugo, 1980; Semeniuk, 1980; Wolanski et al., 1980; Ferdon, 1981; Buckley, 1982; De Lacerda \& Hay, 1982; Naidoo \& Raiman, 1982; Woodroffe, 1982; Plaziat et al., 1983; Woodroffe, 1983; Lakshmanan, 1984; Sherrod \& McMillan, 1985; Singh et al., 1986; Mildenhall \& Brown, 1987; Rutzler \& Feller, 1987; Sing et al., 1987; Vannucci, 1988; Aleem, 1990; Amadi, 1990; Choong et al., 1990; Ibrahim \& Hashim, 1990; Bacon

\& Alleng, 1992; Blasco et al., 1992; Bryant et al., 1992; Barbier, 1993; Saenger \& Siddiqi, 1993;

Ruitenbeek, 1994; Delaney \& Devoy, 1995; Martinez, 1995; Primavera, 1995; Pearce, 1996; Bandyopadhyay, 1997; Bryant et al., 1997; Bryant \& Price, 1997; Primavera, 1997; Ewel et al., 1998; Farnsworth, 1998; Field,

1998; Field et al., 1998a; Gilbert \& Janssen, 1998; Hindson et al., 1998; Kaly \& Jones, 1998; Mimura \&

Nunn, 1998; Tri et al., 1998; Field, 1999; Lee, 1999; Nicholls et al., 1999; Pearce, 1999; Ron \& Padilla, 1999; Rönnbäck, 1999; Arrow et al., 2000; Rönnbäck \& Primavera, 2000; Yap, 2000; Abuodha \& Kairo, 2001; Barbosa et al., 2001; Ewel, 2001; Kaplowitz, 2001a; Kaplowitz, 2001b; Klein et al., 2001; MartinezAlier, 2001; Sathirathai \& Barbier, 2001; Alongi, 2002; Clüsener-Godt, 2002; Oo, 2002; Young \& Bryant, 1992; Moberg \& Rönnbäck, 2003; Wong, 2003; Anthony, 2004; Boyer \& Polasky, 2004; Chee, 2004; Halide et al., 2004; Iftekhar \& Islam, 2004; Tuttle et al., 2004; Badola \& Hussain, 2005; Dahdouh-Guebas et al.,

2005; Danielsen et al., 2005; Hester et al., 2005; Kathiresan \& Rajendran, 2005; Liu et al., 2005; Ramachandran et al., 2005; Twilley et al., 2005; Williams, 2005).

Figure 3. Individual and annual average Impact Factor of pre- and post-tsunami mangrove papers (as recorded in the Web of Science ${ }^{\circledR}$ database) published between 1972 and 2005 (on a logarithmic scale). The 
data also contains the six papers on non-mangrove coastal vegetation and coast-morphological settings that could have the same protective effect, which does not significantly influence the statistical analysis (see text).

There is a clearly identifiable increase in the average Impact Factor following the tsunami disaster (2005 versus any of the previous years). The papers involved are the same referenced in figure 2 .

Figure 4. Graphical representation of a research framework for the in depth study of the potential of mangroves to act as protective barriers on the level of the organism, the vegetation assemblage and the ecosystem. We refer to the text and to the original references indicated for detailed explanations.

Figure1.

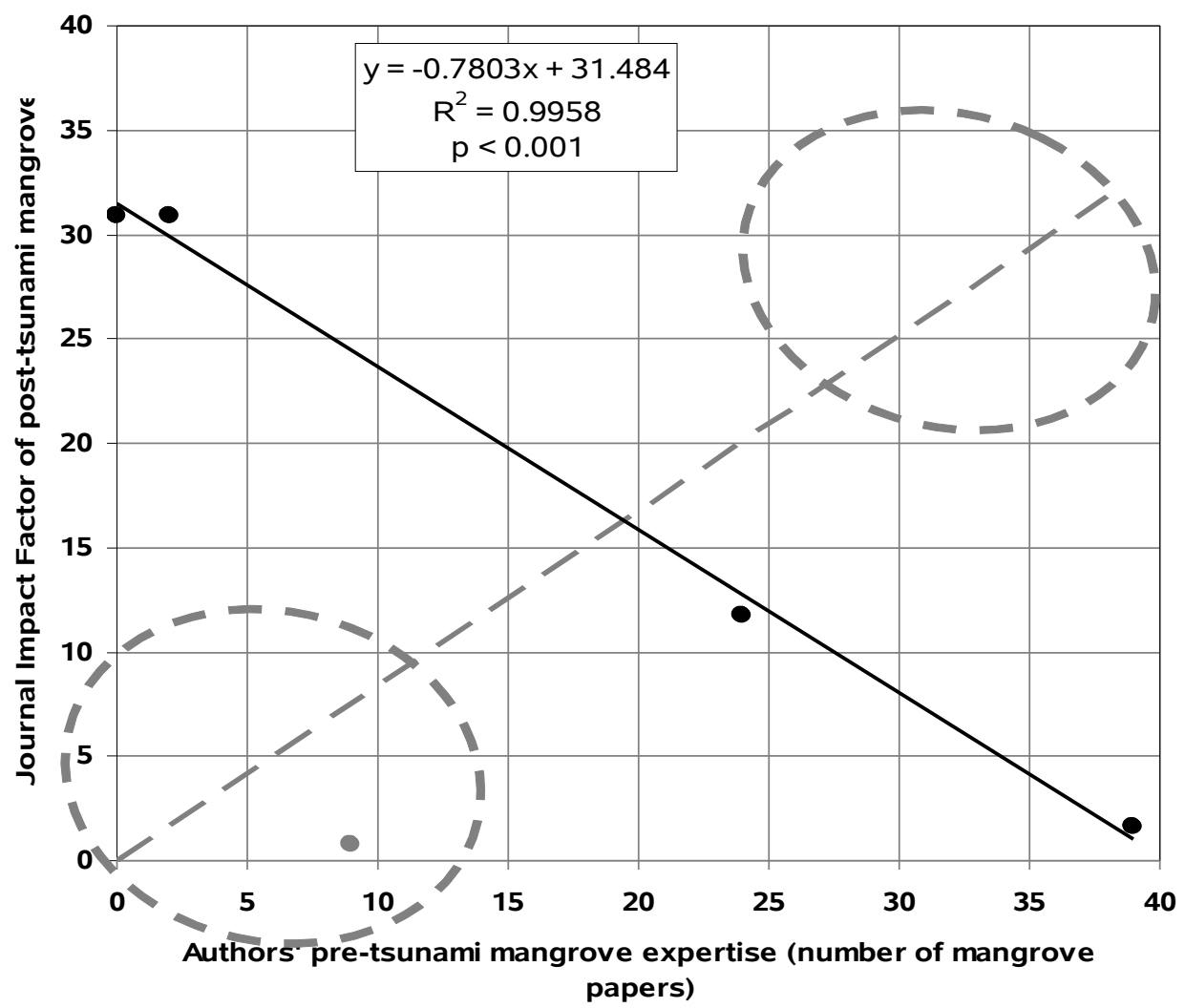


Figure2.

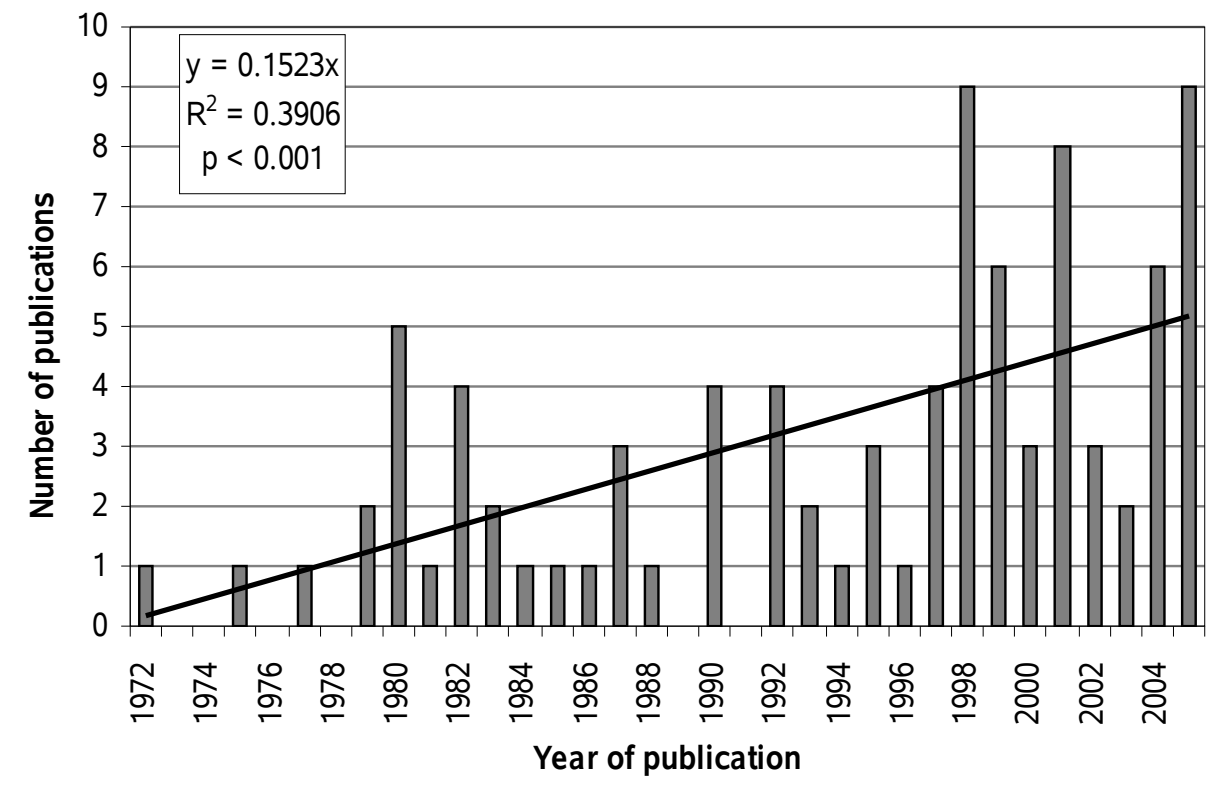

Figure3.

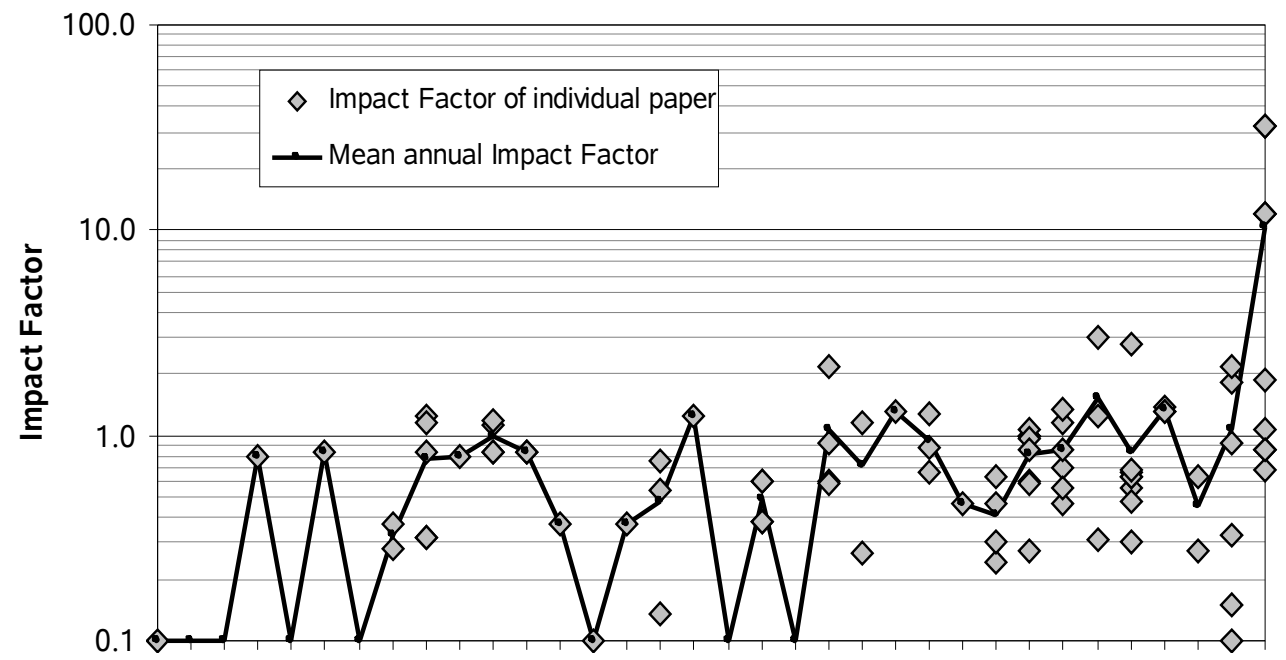

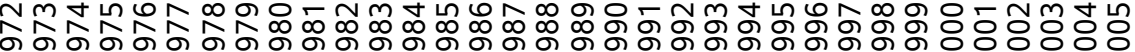

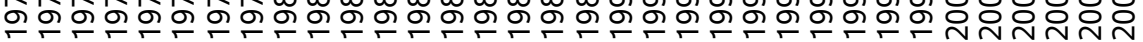
Year of publication 
Figure4.

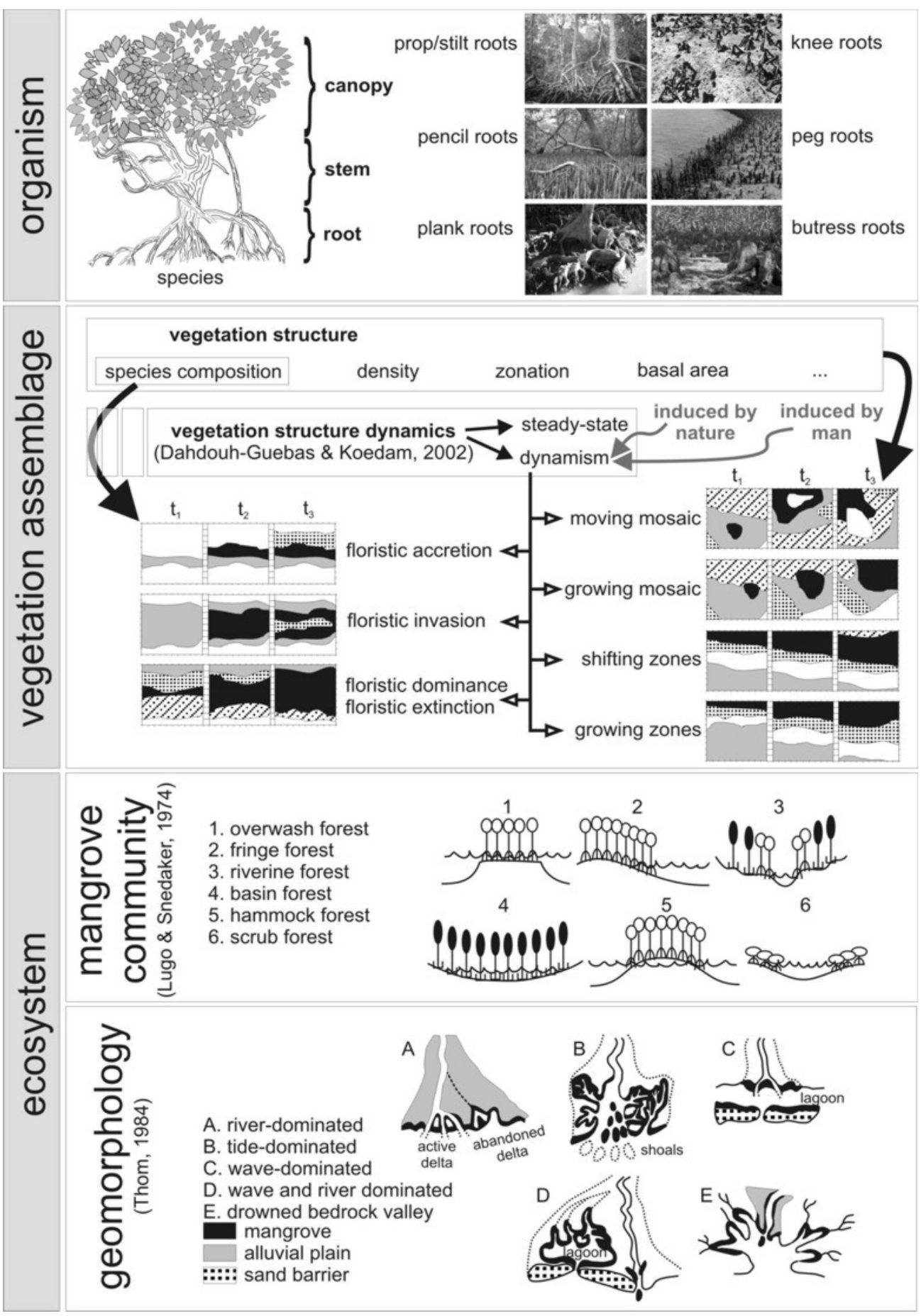

